\title{
The Research of "Audit" Curriculum System Construction and Teaching Innovation
}

\author{
Dongchuan Lin \\ Sichuan Agricultural University \\ Chengdu, China \\ lindongchuan@163.com
}

\author{
Na Mei \\ Sichuan Agricultural University \\ Chengdu, China \\ 1033939740@qq.com
}

\author{
Min Liu \\ Sichuan Agricultural University \\ Chengdu, China \\ 1245255540@qq.com
}

\begin{abstract}
Course of the audit is the core of accounting, auditing, financial management and other professional backbone course. Along with the international convergence of auditing standards, the capital market development, such as changes in the environment, as well as the student main body consciousness enhancement, pressing for auditing teaching to keep pace with The Times. This paper, taking the sichuan agricultural university business school "audit" teaching practice to explore the audit course system is discussed on the basis of reconstruction and teaching innovation, in order to further improve the audit teaching provides a train of thought.
\end{abstract}

\section{Keywords-Audit; Demonstration teaching; Case teaching \\ I. THE NECESSITY OF “AUDIT” CURRICULUM SYSTEM CONSTRUCTION AND TEACHING INNOVATION}

\section{A. The international convergence of auditing standards}

In early 2005, the Ministry of Finance raised the opinion of accounting and auditing standards' international convergence as well as the goal of accounting and auditing standards system construction. In 2006, the new accounting standards and auditing standards system were issued formally, marking that the international convergence of Chinese standards achieved a historic breakthrough. The implementation of the new guidelines adopted the model of popularizing new guidelines after pilot practice, and then it's revised constantly, boosting a continuous convergence of our standards. At the beginning of 2009, The CICPA started the revision project of auditing standards. By the end of 2012 , the criterion's revidion was basically completed. The criterion's revidion and perfection urged the content of auditing teaching to keep pace with the times.

\section{B. Changes in working environment}

On October 30, 2009, the first batch of 28 new shares including Teruide listed on the Shenzhen Stock Exchange, marking the formal establishment of Growth Enterprises Market in China. In March 2010,the CSRC annonced the list of the pilot practice financial company, marking that the margin market was gradually formed in China. The fraud cases of Listed Companies were increasing as the capital market was developing. In March 2010,Yunnan Green Earth became the first IPO fraudulent issuance of shares. It became indispensable to strengthen the classic audit case interpretation in Audit Teaching. In 2010,The fifth national member representative of the CICPA was held, "The new business development" strategy rose to industry strategy. In 2013, the CICPA will release the latest version of "The CPA business guidance directory" (2013). The diversification of accounting firm's business has become an inevitable trend, the traditional and singel auditing professional work teaching has been difficult to meet the current needs of office work.

\section{The aggrandizement of students' subject consciousness}

Most modern college students are post-90s with strong subject consciousness, and they don't like to be conformist, the traditional "spoon-feeding" teaching is hard to adapt to their needs. Most of them are keen to innovative, fashion items, and their performance desires are particularly strong. Therefore, adding students' performance and fashion elements into teaching is more conducive to complete the teaching objectives.

\section{THE RECONSTRUCTION OF THE “AUDIT” CURRICULUM SYSTEM}

"Audit" is the core curriculum of Accounting Principles, Financial Management, Auditing Principles. It's a specialized course after the students have studied Basic Accountancy, Financial accounting, Cost Accounting, Financial Management, Economic Law, Taxition Law and so on, and it's a course which stands on the side of CPA to consider how to supervise financial transaction of companies with the lead of "Chinese CPA standards" and serve for the public. Preliminary study on professional course abount finance, accounting mainly stands in the perspective of enterprises to consider how to do a good job in accounting, investment and financing activities and serve better for enterprises. There is a conflict of interests between 
them to some extent, but there is a synergetic effect.CPA audit could help enterprises to improve the financial management level, and safeguard social public interests better. Therefore, in the new economic environment, changing the structure of the program is a must to improve the financial auditing, accounting, auditing professional knowledge system. The new curriculum structure should include at least the following 5 parts.

\section{A. Audit environment}

Audit environment includes a brief history of the development, the legal liability of audit and the new international environment, this part is maily to lay the foundation and set the tone for auditing teaching.

\section{B. Audit principles}

According to the new standards, it includes practice guidelines, occupation ethics and quality control standards, audit objectives, audit plan, audit evidence, audit sampling, information technology audit, the audit work papers, etc, The Principles of auditing constitute the Audit working masterstroke. Illustrating specificly as shown below:

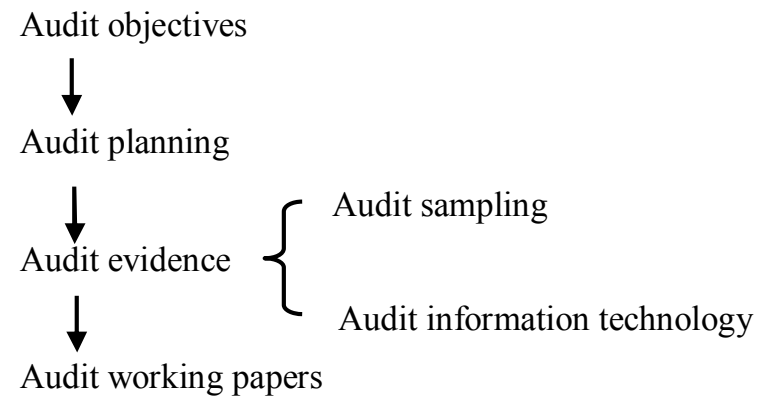

Audit working papers

Audit practice

The audit practice is the part most closely associated with accounting. This part can be used to introduce business cycle, the specific content includes the sale and receivable cycle, purchase and payment cycle, production and inventory cycle, investment and financing cycle, human resources and working cycle, the monetary fund circulation etc. In addition, it can increase some special business audit contents appropriately, such as merger, the period after affairs etc.

\section{The frontier and hot issues of audit}

Audit belongs to the hot point of economic field, auditing teaching could make you pay attention to the latest information in the field. The Curriculum system maily focuses on CPA audit content, so that it could appropriately increase some hot issues related to the government audit, internal audit, international audit(such as knowledge about social security funds audit, internal audit committee )in addition to introduce the latest developments of the CPA industry in the frontier and hot point parts of audit, and keep pace with the times.

\section{Audit case}

Case teaching is a unavoidable link of audit programme. Fraud cases occur frequently among listed companies, the audit field has accumulated frauds various from foreign company to domestic company, such as WorldCom and Yinguangxia and other classic audit cases. In addition, with the development of capital market's diversification it's urgent to pay attention to new case of capital market. Audit case in teaching should include the classic cases and the latest cases.

\section{E. Audit practice}

Audit practice includes simulating actual situation according to Audit teaching software, designing complete story to show the contents of the audit after class, and working in the accounting firm during their internship in summer and winter break.

\section{THE INNOVATION DISCOVERY OF TEACHING METHOD ABOUT AUDIT}

Teaching method is mutually bound to curriculum content and teaching target. The curriculum content depends on teaching method which makes the teaching target realized. Only the relationship of these three items are well dealed with can we realize the training objective of talent. As we all know, audit curriculum is a more theoral and practical subject which is difficult in special skill to some extent. It requires that students don't master the accounting as well as related law and rule, but also have more comparative analysis ability and deduction ability. The traditional teaching method doesn't cater to the needs of talent training about audit in the globalization. The Business Constitute of Sichuan Agricultural University focuses on theoral teaching. Meanwhile it also innovates the teaching model based on the resent audit curriculum.

\section{A. The pattern of micro film}

The micro film named "The Curruption In Shanghai", made by the 2010 grade students in financial management education of business constitute in Sichuan Agricultural University, doesn't confine to the classroom, which wonderfully reveal the outdoor teaching. This film is centered around a passionate hero who ever saled pork. One day, the youth finds the easy way to make money-take accounting and go astry. As the interest increasees by making fake accounting, finally he can't escape the legal sanction. The youth is sad alone in the face of the iron net. Iy is like a dream when he awakes. "The Audit In Imperial Harem", filmed by the two class, 2011 grade, financial management education, makes best use of the advantage of the ancient city of Dujiangyan irrigation county. This film combines the specialized knowledge of audit with the performing art of palace drama, starting to audit with the clue of a lost pearl in imperial harem. Making the film gets students feel the progress that one makes the fake accounting and firm audit, which vividly interprets the responsibility of major auditor and audit work, such as supervision of counting and confirmation. The most important thing in the process of filming is that it further the knowledge about audit for students and expands their knoeledge.

\section{B. Sitcom acting mode of audit}


The morden audit in the eyes of "Baozheng", performed by one class, 2011 grade of financial management(vacational education) brokes the traditional discussion cases.A part of students perform the progress that the company make fake accounting and the professional discretion of accounting firm as well as the application of audit method. etc. Three students play Baozheng, Yuanfang and Zhanzhao, who are ancient people watching audit sitcoms in modern time, and increasingly evaluate the defaud of fake accounting as well as the serious consequence caused by the audit firm. Fashionable factors infused into the performance of audit cases such as Yuanfang gerne, this gerne humouriouly enlightens people and enhance students' vitality of the audit case teaching.

\section{The mode of simulating the awards ceremony}

The modeling performances of "The New Business Development Job Expert Awards" performed by one class,2011 grade of financial management(Corporate Finance), mainly involves two aspects. The first part, the students simulate the Treasury, CICPA, Ministry of Commerce and other central officials making a statement. Their statements mainly relate to the background, policy support and the specific implementation of the new business development strategy, which make us have a certain understanding about new strategy for CPA industry -- the new business development from the macroscopic angle. The second part mainly focuses on the winners' peeches from the accounting firm. This part changed the traditional speech mode, paid more attention to introducing the specific implementation of the new business development, Such as low carbon economy audit, customs audit etc. The performance for the audit focus, especially the policy focus of knowledge plays a good role in promotion.

\section{The mode of variety show}

Post-90s pay special attention to variety shows, especially the talent show. "Only You" employment program performed by class 2,2011 grade of financial management(vacational education)integrated the advantages of the "If You Are the One", The Capable Deserve and "The Voice of China", which is much popular for nearly two years. The appearance of the host simulates lixiang in "The Capable Deserve", jobhunter uses the TV characters such as du lala, the interviewers adopt the model of "Chinese good voice" mentors who all come from big company or a large firm. The interviewer mainly ask for CPA industry personnel training strategy. And if you are the one, the interview will light up the light. This pattern helps everyone learn more about professional knowledge, attention the hotspot through/by entertainment and conforms to the characteristics of contemporary college students' interest in learning.

\section{E. The mode of Live performances}

Class 1,2011 grade of financial management(the direction os corporate financial management) analyse the whole audit business process by simulating the TV program "CPA series of look at finance -- audit project". The dialogue between the host and guests was spiced with the audit business video, participants pointed out and explained errors in video, and then all the members came to the stage and performed "Auditor Is Very Busy" in the form of launch ceremony of "CPA Series Of Look At Finance". The News Broadcast", performed by class 1,2011 grade of financial management(the direction os corporate financial management),combined short sketch, Allegro, dubbing with singing song based on the form of "The News Broadcast" to show the audit knowledge. The form of live performances gave us a sense of reality and made the students feel the audit on the side.

\section{THE SUGGESTION ABOUT IMPROVING THE TEACHING STRATEGY OF AUDIT}

Recently, the teaching method adopted by many audit school in china is traditional, which mainly focuses on teacher.

As classroom teaching basically pays much attention to teacher and the book, emphasizing theory, neglecting practice and the adequate communication between teacher and students, students lack the ability to actively ask questions. Every teacher continuously explores how to improve the teaching effect, develop the teaching method and realize the teaching target. Although we achieve the relatively effect by adopting various teaching methods based on the characteristic and content of the course, there are many problems such as the specifically practical operation of audit and the combination between accounting and audit, which are not greatly took measures. In order to ascertain the target of audit and lay the social foundation for students, we must innovate the teaching method with the development of accounting and audit.

\section{A. The enhancement of audit course for school and constitute}

For the characteristic of audit course, school or constitute can provide the special funds for the teaching reform, purchasing the simulative software of audit course, encouraging teacher to explore the elite courseware and so on, establishing the stage of network teaching and examination database, supplying more self-study resources. In order to encourage students to participate in the activity, school or constitute can hold some video-making contest of audit case to develop the professional skill of graduate and enrich the after-class activity for students.

\section{B. The enrichment of classroom teaching by teacher}

The traditional audit teaching is mainly about theory. We continuously discover that fully spurring students' initiative can make students participate in class and make the effect better. Therefore, when we formulate the cultivate plan, we can appropriately increase the performance experiment of teaching hours for students in order to guide students to study the cutting-edge knowledge of audit domain and major hotpot problems and the implement of the interactive teaching transition. So that it is easy for students to study and broaden their knowledge. If the five strategic implementations of CPA perform in the form of various shows, it can visualize the boring content of the current 
class.

\section{To establish the library of audit case}

This link is not the traditional analysis of teaching case but relates the each part of audit together in the form of study with the aid of multimedia in small classes. Audit case training courses doesn't only require students to participate in case study and discussion, but also earnestly analyze the case and deduct their view in the cases and scenes. At the same time, in order to meet the needs of the audit practice of case, the teacher should further audit practice or collect lots of true cases by other channels. Besides, teachers should select, adapt and package the cases according to cases and the teaching requirement. Finally, the students and the teachers collect a large amount of information and form the database. The teacher should compare with each other and choose the best class by giving the reward, forming a virtuous cycle.

\section{To establish the teaching practice integration platform}

In view of the situation of students' poorly practical ability, on the one hand, school should make students learn about the audit practice through the audit simulation experiment. On the other hand, school can make use of the resources such as alumni association and establish the good cooperation with local government, enterprise and public accounting firms to construct the audit teaching practice base for providing students with auditing practice opportunities in summer and winter vacations .

\section{REFERENCES}

[1] Luo Xiaomin, Innovation of Accounting Teaching, Guide to Business,vol.10,pp.233-234,2012.

[2] Wang Qingli, Reform of the teaching method of auditing course, China Urban Economy,vol.02,pp.215-216,2012.

[3] Tang Wenjun, Discussion about the reform of the auditing course's examination, Journal of Hubei University of Economics(Humanities and Social Sciences),vol.12,pp.196-197,2011.

[4] Wu Yingjie, Application of case teaching method in the teaching of audit, Co-operative Economy \& Science,vol.15,pp.112-113,2011.

[5] $\mathrm{Xu}$ Guili,Problems and suggestions of auditing teaching case, Commercial Accounting,vol.19,pp.66-67,2010.

[6] Cheng Zhiqiao, Discussion on demonstration teaching, Modern Skill Development,vol.10,pp.37,2003.

[7] Wang Cuiying, The innovation of human resource management course, Modern Enterprise,vol.07,pp.68-69,2011.

[8] Chen Bing, Research on the audit environment harmonious construction, Assets and Finances in Administration and Institution,vol.09,pp.58-59,2012.

[9] Zhang Jiaojiao, Problems and countermeasures that audit environment exists, Science \& Technology Vision, vol. 06, pp.37-38,2012.

[10] Qian Feng, Reflections on Auditing Environment in China, Journal of Nanjing Forestry University(Humanities and Social Sciences Edition),vol.02,pp.99-102,2008. 